\title{
Fan Phenomena: Harry Potter (Review)
}

Frankel, V.E. (2019) Fan Phenomena: Harry Potter (eds) Frankel V.E. Bristol: Intellect Books.

\section{NICHOLAS FURZE, Canterbury Christ Church University Co-Guest Editor}

It has been 12 years since Harry Potter and the Deathly Hallows, the last in the initial series of Harry Potter books was published, and yet the franchise remains very popular, with various films, plays, computer games, theme park rides and websites still being created, and enjoyed, by people all over the globe. All of this has helped feed a large and diverse fanbase whose engagement with the series remains just as strong as it was when the initial book series was first published. It is this fan community that is the focus of Frankel's edited collection, which covers a wide variety of subjects from the more official expanded sources, such as Erin Pyne's consideration of The Wizarding World of Harry Potter at Universal Studios to the more unofficial fan-created stories, films and online activities, that have allowed the fan community to maintain its loyal base over the years. Similarly, this edited collection also includes interviews with various practitioners in the Harry Potter fan community, with their insights providing useful contextual information which could be useful for future scholars working in this field. Therefore, this edited collection makes a valuable contribution within the growing field of fan studies but it can also be enjoyed by those same fan communities who feature in the text.

In Buffy, Hamilton and Jon Snow go to Hogwarts: Literary Affordance and the Hogwarts Houses as Interpretative Framework and Rhetorical Tool, Jessica Hautsch creates a convincing analysis of the myriad ways in which the series' device of sorting every student into houses has been taken up and developed further by online blogs and websites to create new interpretative communities (Fish, 1980). These communities reinterpret what the Hogwarts Houses mean and apply it to themselves, as well as in debates surrounding other characters in fiction.

Similarly, in Surveying Fanworks: Art, Dance, Fic, Music and Community, Madeline Wilson provides a broad overview of the myriad ways in which the Harry Potter fan community has engaged with, and reinterpreted, the core seven novels, and then shared their alternative narratives online. She looks at how those reinterpretations are in conversation with each other, 
such as some fan artworks being created as adaptations of fan fictions. Wilson makes a particularly intriguing point when she observes how J.K. Rowling's laissez faire approach to fan works (only requiring that they are not obscene) allowed these fan communities to thrive in the early 2000s. She contrasts this approach with the attitudes of authors such as Anne Rice and Orson Scott Card, who take a harsher stance on the issue. This comparison raises a particularly intriguing point for the analysis of fan communities and their relationship with creators that could benefit from being analysed further in future research.

Overall, the assorted essays and interviews in this collection present a thoughtful analysis into how the Harry Potter fan community has developed over the past 22 years. Moreover, they present a convincing argument as to how the same community will continue to develop, especially while the official series continues to expand. All of this makes Fan Phenomena: Harry Potter an intriguing addition to a growing field of study, while at the same time provoking a number of questions which future research would benefit from exploring further.

\section{References}

Fish, S. (1980) Is There a Text in This Class? The Authority of Interpretative Communities, Cambridge: Harvard University Press.

Nicholas Furze is a Sessional lecturer at Canterbury Christ Church University. He is also currently working on his $\mathrm{PhD}$ which is entitled 'Adapting History: Applying Adaptation Theory to Historical Film and Television', and has presented his research at the annual conferences for the British Association of Film, Television and Screen Studies (2016 and 2017), The Association of Adaptation Studies (2016 and 2017), The Media, Communication and Cultural Studies Association Postgraduate Network Conference (2018), and at The Game of Thrones Symposium at the University of Hertfordshire (2017).

Email: nicholas.furze@ canterbury.ac.uk 